\title{
THE FIRST COLLECTION OF PINNASA VOLUBILIS (LOASACEAE) FOR THE FLORA OF ARGENTINA
}

\author{
Dylan H. Cohen ${ }^{1}$ \& Alejandra Maza Granero²
}

\begin{abstract}
${ }^{1}$ Rancho Santa Ana Botanic Garden, 1500 North College Avenue, Claremont, California, United States of America; dcohen@rsabg.org (author for correspondence).

${ }^{2}$ RP 11 Moquehue, 8345 Neuquén, Argentina; patagoniawildflowers@gmail.com
\end{abstract}

\begin{abstract}
Cohen, D. H. \& A. Maza. 2019. The first collection of Pinnasa volubilis (Loasaceae) for the Flora of Argentina. Darwiniana, nueva serie 7(2): 330-334.

Plants of Pinnasa (Loasaceae) are vining or rosette-forming perennial herbs distributed across the southern Andes and Patagonian Steppe. Three species were formerly cited for Argentina. We report a fourth species, $P$. volubilis, until now known only from southern Chile, for the first time from Neuquén province. A description of the species, together with photos, a distribution map, and a key for Pinnasa species in Argentina are here provided.
\end{abstract}

Keywords. Flora; Neuquén; Pinnasa; taxonomy.

Resumen. Cohen, D. H. \& A. Maza. 2019. La primera colección de Pinnasa volubilis (Loasaceae) para la Flora de Argentina. Darwiniana, nueva serie 7(2): 330-334.

\begin{abstract}
El género Pinnasa (Loasaceae) incluye hierbas perennes, trepadoras o erectas, distribuidas en el sur de los Andes y la estepa patagónica. Tres especies fueron citadas para la Argentina con anterioridad y una cuarta, $P$. volubilis, hasta el presente sólo conocida para el sur de Chile, se cita por primera vez para la provincia de Neuquén. En este trabajo se presentan una descripción de la especie, fotografías, un mapa de distribución y una clave para identificar a las especies de Pinnasa que habitan en la Argentina.
\end{abstract}

Palabras clave. Flora; Neuquén; Pinnasa; taxonomía.

\section{INTRODUCTION}

The genus Pinnasa Weigend \& R.H. Acuña comprises about 10 species that were previously assigned to Loasa ser. Pinnatae Urb. \& Gilg. Molecular phylogenetics has demonstrated that L. ser. Pinnatae is distantly related to Loasa s.str. and sister to a clade containing Caiophora C. Presl and Scyphanthus Sweet. Pinnasa share many traits with Caiophora and Scyphanthus including elaborate floral scales, finely dissected or pinnately compound leaves, and deeply pitted seeds with fenestrated anticlinal walls (Hufford et al., 2005; Acuña et al., 2017). Plants of Pinnasa differ due to their fringed-undulate petal margins, and by retaining the pleisomorphic condition of apically dehiscing capsules, traits that are mostly or entirely absent from Caiophora and Scyphanthus. Pinnasa differs from Loasa by having pinnatifid to pinnately compound leaves, erect flowers, fringed-undulate petal margins, terminal hilar scars and absence of stinging setae. 
Species of Pinnasa are distributed across the southern Andes of Argentina and Chile, from the foothills of the western cordillera to the eastern Patagonian Steppe.

There are currently three species of Pinnasa recorded for Argentina (Weigend et al., 2008). They are distributed in the Andean cordillera and Patagonia from Mendoza to Santa Cruz Province. Previously, Pinnasa volubilis (Dombey ex Juss.) Weigend \& R.H. Acuña was only recorded from Chile. While doing field work for a revisionary study of Pinnasa in Argentina and Chile (Cohen in prep), $P$. volubilis was collected in Neuquén Province, near the border with Chile. Herbarium material was also studied, but no previously existing specimens of $P$. volubilis from Argentina were found. The scope of this work is to shed light on this new occurrence.

\section{MATERIALS AND METHODS}

The material analyzed was collected from one locality in the province of Neuquén and deposited in CORD, SI, and RSA (Thiers, 2019). This collection was then compared to specimens, including type material, of other species of Pinnasa and related Loasaceae at CONC, CORD, HAL, MERL, P, SI and W.
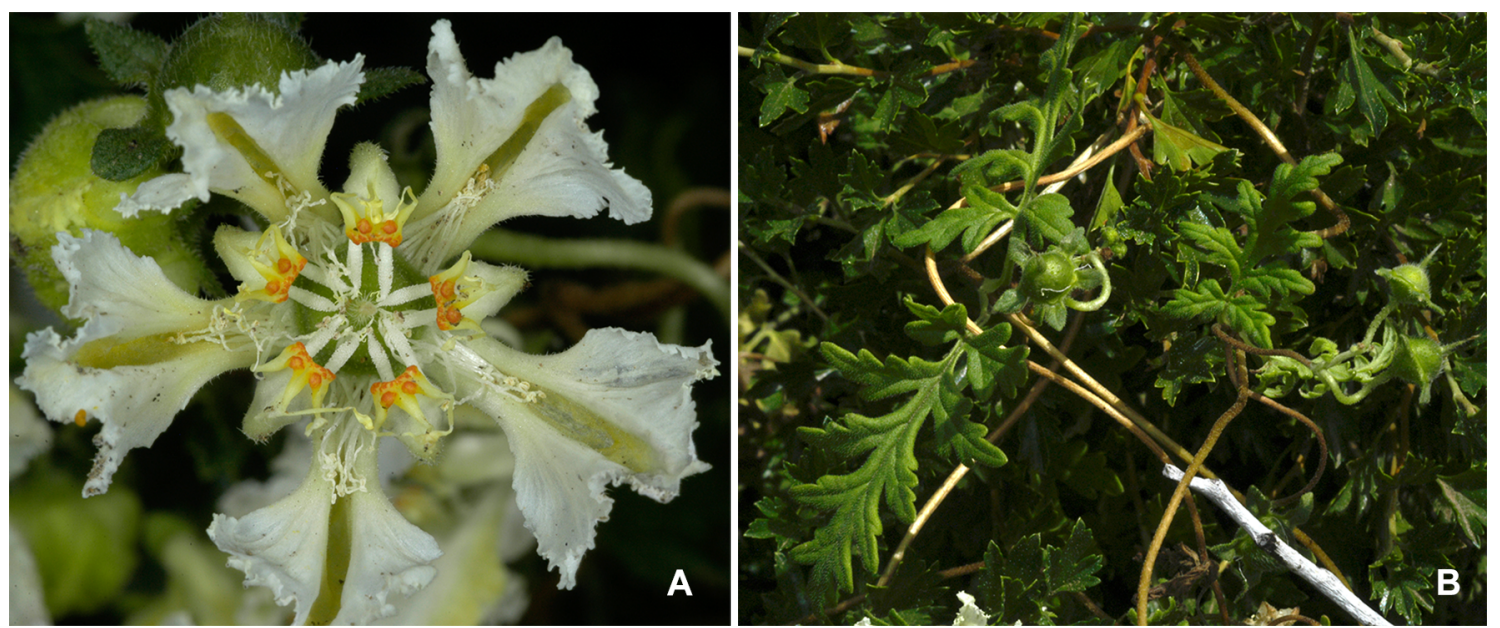

Fig. 1. Pinnasa volubilis. A, flower. B, vining habit and pinnatifid leaf. Photo by D. Cohen, of Cohen 74 (SI). Color version at http://www.ojs.darwin.edu.ar/index.php/darwiniana/article/view/858/1174
Pinnasa volubilis (Dombey ex Juss.) Weigend \& R.H. Acuña, Taxon 66(2): 374. 2017. Loasa volubilis Dombey ex Juss., Ann. Mus. Natl. Hist. Nat. 5: 26. 1804. TYPE: Chile. 1782/1783, J. Dombey s.n. (lectotype P 02273153! photo, designated by Acuña et al., Taxon 66(2): 374. 2017; possible isolectotypes $\mathrm{P} 02273154$ ! photo; P 02273155!). Figures 1-2.

Loasa volubilis var. alpina Poepp., Fragm. Syn. Pl.: 24. 1833. Loasa artemisiifolia Poepp. ex Urb. \& Gilg, Monogr. Loasacearum: 173, 359. 1900. TYPE: Chile. Sierra velluda ad Antuco, 1829, E. Poeppig, Diar. 945 (syntypes HAL 0121358! photo; P 04589413! photo; W 0017739! photo).

Note: Although Loasa amabilis was suggested to be a synonym of Loasa volubilis (= Pinnasa volubilis) in the Catalogue of the Southern Cone (Weigend et al., 2008), we treat it here as a synonym of Loasa argentina Urb. \& Gilg. ex Speg.

Herbaceous vine, stems ca. 100-200 cm long (?), 1-2 $\mathrm{mm}$ diam. Stem tan to light brown, epidermis exfoliating with age, with simple scabrid trichomes and shorter, inconspicuous, glochidiate trichomes. Root system unknown. 

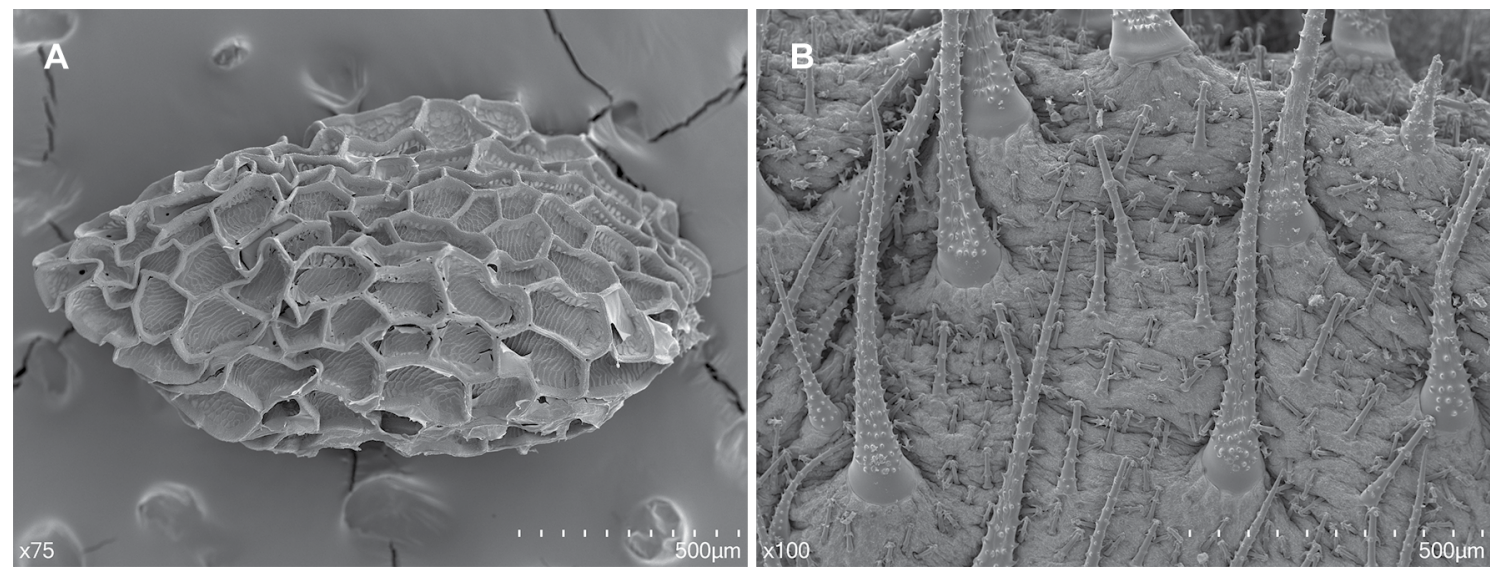

Fig. 2. Pinnasa volubilis. A, seed. B, larger scabrid and smaller glochidate trichomes at roof of ovary. Micrograph material from Cohen 74 (SI). Color version at http://www.ojs.darwin.edu.ar/index.php/darwiniana/article/view/858/1174

Leaves opposite, petiole sheathing, 10$34 \mathrm{~mm}$, with scabrid and short glochidiate trichomes, lamina $22-88 \times 12-64 \mathrm{~mm}$, deeply pinnatifid, sometimes appearing bipinnatifid or compound, adaxial surface with many scabrid, few glochidiate, and glandular trichomes, abaxial surface with scabrid trichomes mostly along margins and veins, and few glochidiate trichomes. Inflorescences to $35+\mathrm{cm}$ long, lax, open, winding with axillary branches, flowering branches opposite, one- to many-flowered, each flower horizontal to erect in anthesis with two petiolate, frondose bracts, 9.2-34 × 5-23 mm, with indumentum similar to that of the leaves; pedicels 7-10 $\mathrm{mm}$ long during anthesis, with indumentum similar to that of the stem and petioles, lengthening considerably in fruit (up to $30 \mathrm{~mm}$ ). Sepals five, ovate, $1.9-6 \times 1.3-3.2$ $\mathrm{mm}$; with a main vein, margins entire, adaxially covered in scabrid trichomes with few glochidiate trichomes near margins, abaxially covered in glochidiate trichomes with scabrid trichomes on veins and margins. Petals five, spreading, strongly unguiculate, proximally clawed, distally triangularly, white to pale yellow, with a distinct longitudinal green band along the middle of abaxial surface, 8.5-12.5 mm long, with laciniate margins, adaxially with very short, sparse glochidiate and scabrid tricomes, distally with flattened elongated cells; abaxially with more glochidiate and scabrid trichomes. Nectar scales five, distinctly L-shaped in lateral view and deeply cucullate, 4.4-7 × 1.9-4 mm, pale white to yellow/green, red markings apically, papillose at the base, with the neck thickened into shallow double arch, dorsal threads three, ca. $4 \mathrm{~mm}$ long, attached to either the winged margins of scale or the upper third of central ridge, slightly flattened and expanded apically. Staminodes two per scale, 3.8-6.5 $\mathrm{mm}$ long strongly L-shaped, the base flattened, at about 2 $\mathrm{mm}$ from the base thickened in a knob, the apex filiform. Stamens ca. 50, filaments 4-7 mm long. Style 3-6 mm, with shallow grooves that extend onto the stigma, covered in scabrid trichomes most of its length, proximally, distally glabrous. Ovary half-inferior, roof covered densely in long scabrid and short glochidiate trichomes, inferior part mostly with glochidiate trichomes and a few scabrid trichomes. Fruit a globose capsule, 4-11 $\times 5.5-10 \mathrm{~mm}$, apically dehiscent by three valves. Seeds 1.4-2 × 0.6-1.1 mm, ovoid, dark brown/ black with a reticulate testa with well-developed anticlinal walls, and indistinguishable hilar cone.

Distribution and habitat. This species is found in Chile, from Valparaíso south to Los Ríos Region (Rodríguez et al., 2018). In the present publication, its distribution is expanded to a single location in Neuquén Province, Argentina (Figure 3). The population found in Argentina is located in a disturbed habitat surrounded by Nothofagus antarctica (G. Forst.) Oerst., "ñire", near the Ski Center in Cerro Caviahue. 


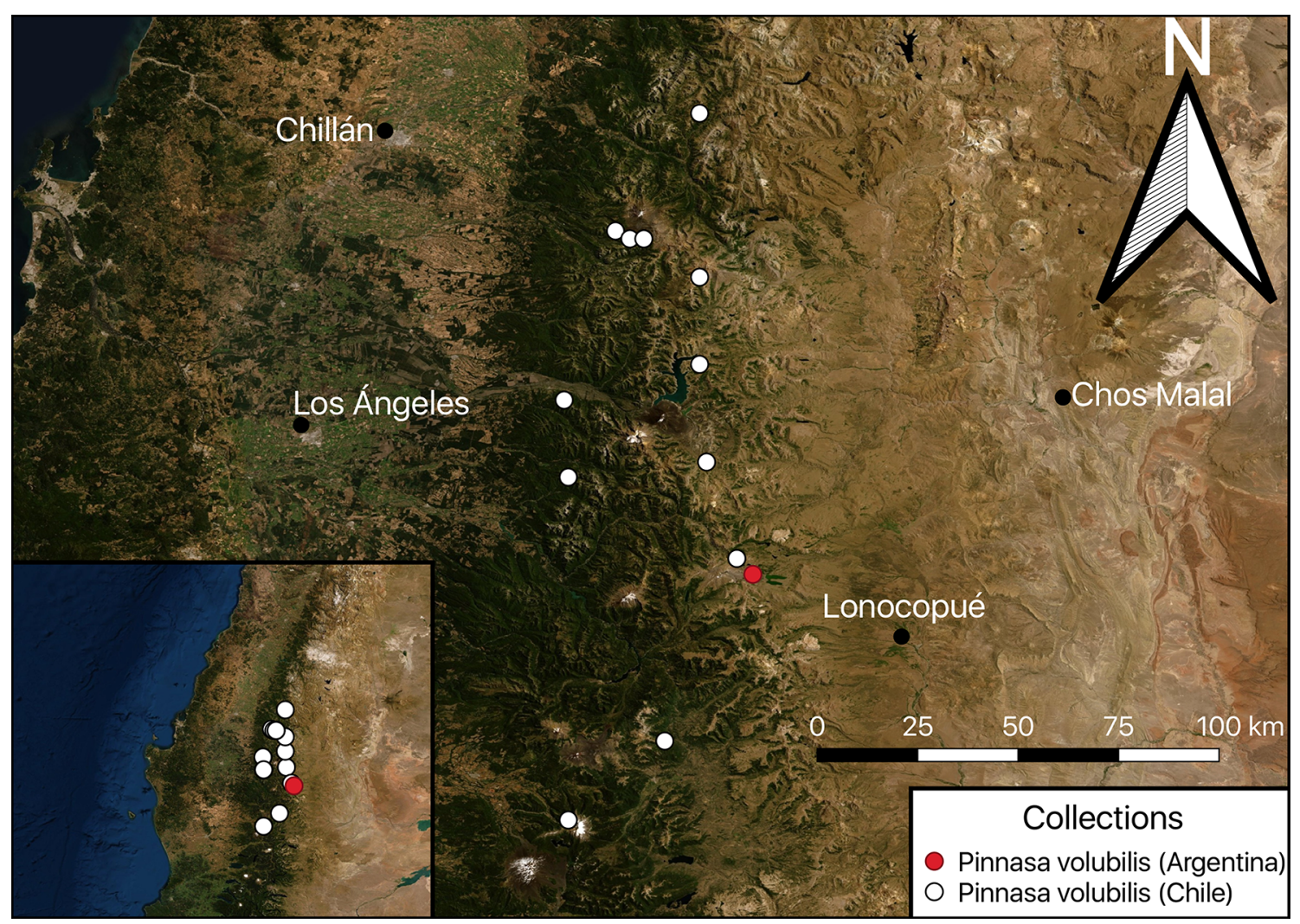

Fig. 3. Known collections of $P$. volubilis from Argentina and Chile. Color version at http://www.ojs.darwin.edu.ar/ index.php/darwiniana/article/view/858/1174

It is likely that other populations of $P$. volubilis could be found in similar areas to the north and south within the Argentine Andes. Seeds are wind dispersed and plants tend to grow in disturbed areas or cliff habitats.

Observations. With this new record, there are now at least three species of vining Pinnasa from Argentina, one of which, L. argentina, has yet to be transferred to Pinnasa. Pinnasa volubilis differs from P. bergii (Hieron.) Weigend \& R.H. Acuña and L argentina by having much larger flowers and leaves. Loasa argentina could perhaps be confused with $P$. volubilis, but plants of the former species have linear leaflets whereas plants of the latter species have irregularly lobed and generally larger leaflets. In addition, $P$. volubilis has pronounced sheathing petioles in comparison to the other vining plants.

\section{Additional material examined}

ARGENTINA. Neuquén. Depto. Ñorquín, Cerro Caviahue, Vegetated area near ski slopes, 1805 m s.m., $37^{\circ} 51^{\prime} 43.308^{\prime}$ ' S, $71^{\circ} 5^{\prime}$ ' $14.28^{\prime}$ 'W, 21-I-2018, Cohen 74 (CORD, RSA, SI).

CHILE. Araucanía. Prov. Malleco, Curacautín, 1060 m s.m., 12-II-1969, Montero 8239 (CONC). Biobío. Prov. Biobío, Santa Bárbara, Cordillera de Los Andes: Reserva Nac. Ralco, road to Laguna Verde, 1539 m s.m., $37^{\circ} 53$ ' 33.8” S, $71^{\circ} 21^{\prime} 37.0^{\prime \prime}$ W, 17-I2004, Darwin Core Initiative 770 (CONC, E, SGO). Prov. Ñuble, Termas de Chillán, 4-II-1948, Castillo s.n. (CONC). Prov. de Nuble, Nevados de Chillán, Neues Wegstück zu den Termas oberhalb der Puente Lechería, ca. 1600 m s.m., 26-II-1981, Grau 3055 (M). Prov. Biobío, Termas de Chillán, 1925 m s.m., 36 52’ 38.532" S, 71 ${ }^{\circ} 28^{\prime} 52.392 ”$ W, 22-I-2017, Cohen 25 (CONC, RSA, SGO). Prov. Nuble, Límite de la Reserva Nac. Nuble, 1250 m s.m., 14-II-2003, Mihoc 6799 (CONC). 


\section{Key to Pinnasa in Argentina}

1. Plant ascending, erect or rosette-forming cespitose, stem epidermis not exfoliating ...................................... 2

1. Plant twining, stem epidermis exfoliating with age ................................................................................... 3

2(1). Plant ascending or erect, petals white, nectar scales white with orange apex ........................ Pinnasa pinnatifida

2. Plant cespitose, petals yellow, nectar scales white, distally elongated, apex flattened ........................ Pinnasa nana

3(1). Petals yellow, nectar scale yellow/orange, fruit obconical .......................................................... Pinnasa bergii

3. Petals white, nectar scale white/orange, fruit globose ................................................................. Pinnasa volubilis

\section{ACKNOWLEDGMENTS}

We thank the herbarium curators at CORD, MERL, SI, SGO, and CONC for sending images of specimens and loans. We also thank Dr. Manuel J. Belgrano, Dr. Lucinda McDade, and two anonymous reviewers for helpful comments that improved manuscript. This work was supported by funding obtained thru Rancho Santa Ana Botanic Garden graduate student research grant.

\section{BIBLIOGRAPHY}

Acuña, R., S. Fließwasser, M. Ackermann, T. Henning, F. Luebert, \& M. Weigend. 2017. Phylogenetic relationships and generic re-arrangements in "South Andean Loasas"(Loasaceae). Taxon 66(2): 365-378.
Hufford, L., M.M. McMahon, R. O’Quinn, \& M.E. Poston,. 2005. A phylogenetic analysis of Loasaceae subfamily Loasoideae based on plastid DNA sequences. International Journal of Plant Sciences 166(2), 289-300.

Rodríguez, R., Marticorena, C. ${ }^{\dagger}$, Alarcón, D., Baeza, C., Cavieres, L., Finot, V. L., Fuentes, N., Kiessling, A., Mihoc, M., Pauchard, A., Ruíz, E., Sánchez, P. \& Marticorena, A. 2018. Catálogo de las plantas vasculares de Chile. Gayana, Botanica. 75(1): 1-430.

Thiers, B. [regularly updated, accessed 2019] Index Herbariorum: a global directory of public herbaria and associated staff. New York Botanical Garden's Virtual Herbarium, http://sweetgum.nybg.org/ih

Weigend, M.; J. Grau \& M. Ackermann. Loasaceae, in: F. O. Zuloaga, O. Morrone \& M. J. Belgrano (eds.), 2008. Catálogo de las plantas vasculares del cono sur : (Argentina, sur de Brasil, Chile, Paraguay y Uruguay). Monographs in systematic botany from the Missouri Botanical Garden 107: 2413-2424. 